\title{
THE ANALYSIS OF IMPLEMENTING SAFETY MANAGEMENT SYSTEM (SMS) TO IMPROVE THE FLIGHT SAFETY
}

\author{
Eko Poerwanto \\ Departemen Teknik Industri \\ Sekolah Tinggi Teknologi Adisutjipto \\ Jl. Janti Blok-R Lanud Adisutjipto, Yogyakarta 55198 \\ Email: ekoevtas@gmail.com
}

\begin{abstract}
Flight safety can be created only by good cooperation from all stakeholders in aviation. In other words, each flight stakeholder has the responsibility and contribution to the flight safety. This condition shows the importance of analyzing the implementation of Safety Management System (SMS) in the aviation industry, because it is a part of the State Safety Program (SSP) in accordance with ICAO standard. The research method is presented descriptively related to the aviation safety regulations with the current conditions of implementing flight safety. The results showed the implementation of the Safety Management System (SMS) by each flight stakeholder was running, but the "Flight Safety Promotion" activity had not been able to run properly, because there were no periodic reports issued by regulators on the Aviation Safety Program. Another thing is the violation of the implementation of Safety Management System (SMS) has not been through the "Aviation Professional Assembly", so that the personnelwho committedthe violations will get objective punishment.
\end{abstract}

Keywords: Flight Safety, Safety Management System

\section{Pendahuluan}

Keselamatan penerbangan dapat tercipta hanya oleh kerjasama yang baik dari seluruh stakeholder dalam penerbangan. Artinya, setiap stakeholder penerbangan memiliki tanggung jawab dan kontribusi terhadap terciptanya keselamatan penerbangan. Sebagai bagian dari suatu sistem, apabila salah satu institusi tidak memainkan peranannya dengan baik, walaupun institusi-institusi yang lain telah menunjukkan kinerja yang baik, tetap saja keselamatan penerbangan akan sulit terwujud. Selain permasalahan keselamatan pada penerbangan di Indonesia, permasalahan yang lain adalah tentang pelayanan penerbangan berkaitan dengan delay atau kinerja airline yaitu on time performance yang saat ini sering dipermasalahkan konsumen. Hal ini menunjukkan adanya banyak permasalahan di industri penerbangan di Indonesia yang cukup kompleks dan sistemik. Kondisi tersebut menunjukkan pentingnya analisis pelaksanaan Safety Management System (SMS) pada industri penerbangan, karena walaupun SMS wajib dilaksanakan oleh seluruh stakeholder yang ada, tetapi incident dan kecelakaan dalam penerbangan masih ada.

Peraturan Menteri Perhubungan Republik Indonesia nomor PM 93 tahun 2016, tentang Program Keselamatan Penerbangan Nasional, dan Peraturan Menteri Perhubungan Nomor KM 20 tahun 2009 tentang Sistem Manajemen Keselamatan (Safety Management System). Regulasi tersebut ditetapkan untuk menciptakan ergonomi makro pada industri penerbangan di Indonesia yaitu sesuai dengan Undang-Undang Nomor 1 tahun 2009 tentang Penerbangan dalam Pasal 1, Butir 48 menyatakan bahwa "Keselamatan Penerbangan adalah suatu keadaan terpenuhinya persyaratan keselamatan dalam pemanfaatan wilayah udara, pesawat udara, fasilitas umum lainnya". Untuk penyedia jasa penerbangan di Indonesia bahwa tingkat 
keselamatan penerbangan dapat dicapai dengan berfungsinya semua unsur terkait antara satu dengan lainnya terhadap penyedia jasa penerbangan.

\section{Program Keselamatan Penerbangan Nasional}

Keselamatan Penerbangan adalah suatu keadaan terpenuhinya persyaratan keselamatan dalam pemanfaatan wilayah udara, pesawat udara, bandar udara, angkutan udara, navigasi penerbangan, serta fasilitas penunjang dan fasilitas umum lainnya.Safety Management Sistem (SMS) adalah pendekatan sistematis untuk mengelola keselamatan, meliputi struktur organisasi, pertanggungjawaban, kebijakan dan prosedur. Setiap penyedia jasa penerbangan adalah badan usaha angkutan udara, badan usaha bandar udara, unit penyelenggara bandar udara, penyelenggara pelayanan navigasi penerbangan, badan usaha pemeliharaan pesawat udara, penyelenggara pendidikan dan pelatihan penerbangan, dan badan usaha rancang bangun dan pabrik pesawat udara, mesin pesawat udara, baling-baling pesawat terbang dan komponen pesawat udara (wajib menjalankan SMS).

Menurut UU no. 1 thn 2009, tentang Penerbangan, bagian keempat "Sistem Manajemen Keselamatan Penyedia Jasa Penerbangan", pasal 314 :

1. Setiap penyedia jasa penerbangan wajib membuat, melaksanakan, mengevaluasi, dan menyempurnakan secara berkelanjutan sistem manajemen keselamatan (safety management system) dengan berpedoman pada program keselamatan penerbangan nasional.

2. Sistem manajemen keselamatan penyedia jasa penerbangan sebagaimana dimaksud pada ayat (1) harus mendapat pengesahan dari Menteri.

3. Setiap penyedia jasa penerbangan yang melanggar ketentuan sebagaimana dimaksud pada ayat (1) dikenakan sanksi administratif berupa :

a. peringatan;

b. pembekuan izin; dan/atau

c. pencabutan izin.

Berdasarkan Peraturan Menteri Perhubungan Republik Indonesia nomor PM 93 tahun 2016, tentang Program Keselamatan Penerbangan Nasional, Tim Database Program Keselamatan Penerbangan Nasional (State Safety Programme Database Group) mempunyai tugas dan tanggung jawab sebagai berikut:

a. menghimpun dan memutakhirkan data Laporan Hasil Pengawasan Inspektur Penerbangan, Laporan Kecelakaan atau Kejadian Serius, Laporan Safety Management System (SMS) dan Laporan Sukarela;

b. memberikan informasi atas keselamatan penerbangan kepada Ketua Pelaksana Program Keselamatan Penerbangan Nasional;

c. melakukan verifikasi atas kebenaran laporan keselamatan penerbangan serta melakukan pertukaran/perbandingan data laporan keselamatan penerbangan;

d. memastikan sistem database selalu dalam keadaan dapat dipergunakan;

e. memastikan kerahasiaan data (sebagai data keeper) agar tidak dapat diakses oleh pihakpihak yang tidak bertanggungj awab langsung maupun pihak ketiga;

f. mengkoordinasikan kepada unit-unit yang bertanggungjawab di lingkungan Direktorat Jenderal Perhubungan Udara, Kantor Otoritas Bandar Udara, KNKT dan penyedia jasa penerbangan, agar memutakhirkan data keselamatan penerbangan tepat pada waktunya;

g. melakukan evaluasi atas data-data dan laporan keselamatan penerbangan. 
Berkaitan dengan Struktur Pengelolaan Database Keselamatan Penerbangan Nasional adalah sebagai berikut :

Yang dimaksud dengan Penyedia Jasa Penerbangan, menurut UU no. 1 thn 2009, tentang Penerbangan :

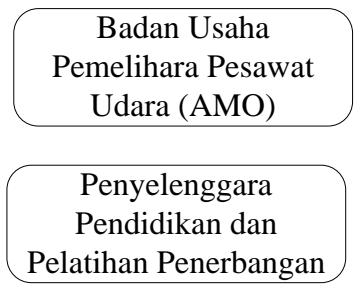

Badan Usaha Angkutan Udara (Airline)

Penyelenggara Pelayanan Navigasi Penerbangan (AirNav)
Badan Usaha Rancang

Bangun dan Pabrik

Pesawat Udara,

(Manufactur, dll)

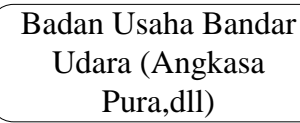

Badan Usaha Bandar Pura,dll)

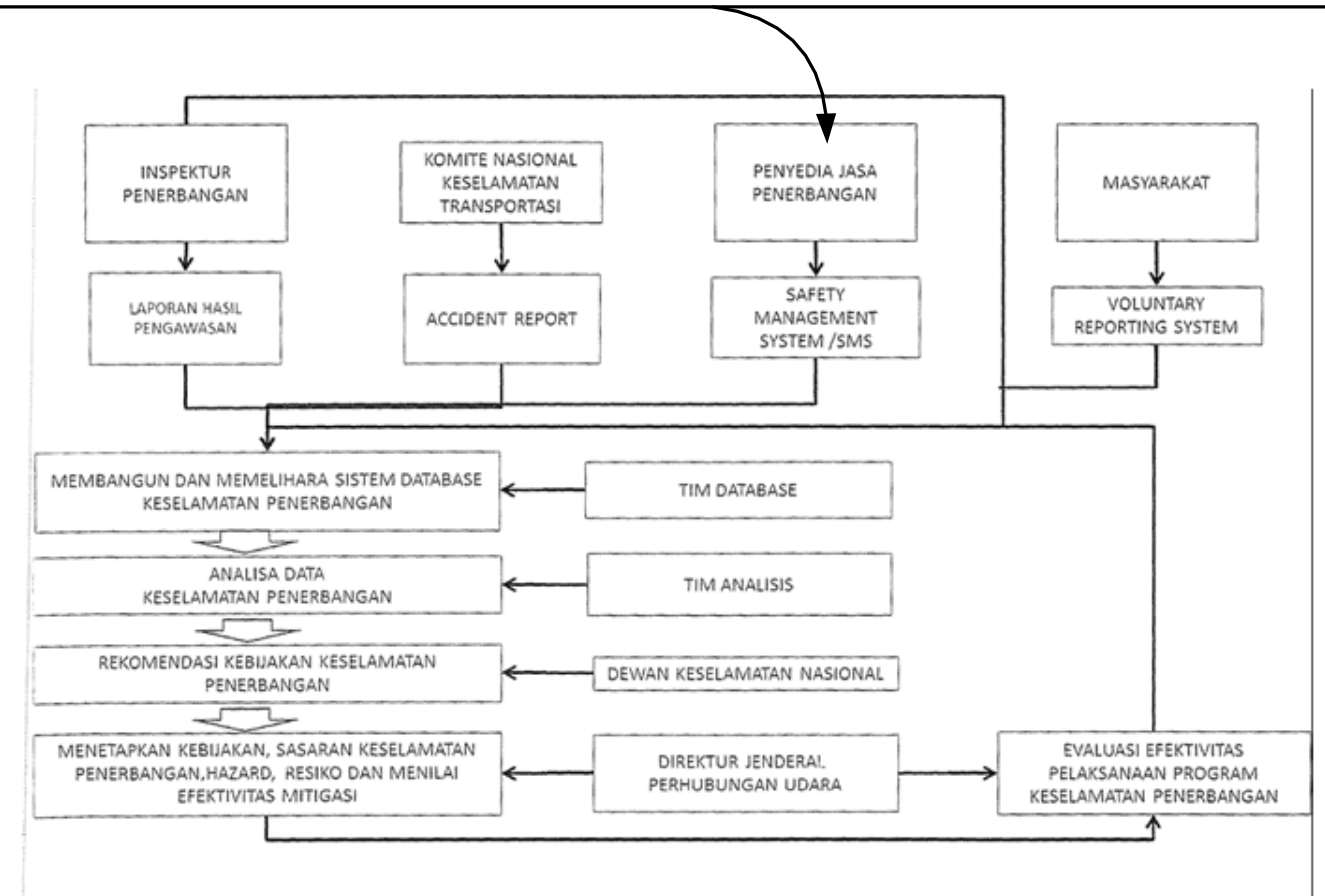

Gambar 1 Seluruh Stakeholder Industri Penerbangan Wajib Menjalankan dan Melaporkan ke Regulator Pengelolaan Database Keselamatan Penerbangan Nasional (Sumber : Peraturan Menteri Perhubungan nomor PM 93 tahun 2016)

\section{Metodologi Penelitian}

\subsection{Identifikasi Masalah (Problem Identification)}

Keselamatan Penerbangan sebagai visi dan misi yang utama dari Industri Penerbangan Global dapat dimulai dari seluruh aspek operasional sistem yang dilaksanakan. Sesuai dengan studi literatur, masalah penerapan SMS dalam meningkatkan keselamatan penerbangan di Indonesia diidentifikasi berdasarkan terbitnya regulasi yang dipraktekkan dalam operasional penerbangan, kemudian diterjemahkan ke dalam rumusan masalah yang akan menjadi tujuan dan penyempurnaan pelaksanaan Program Keselamatan Penerbangan Nasional.

\subsection{Pengumpulan Data}

Untuk melakukan studi ini diperlukan data-data terkait dengan layanan informasi pada penerbangan di Indonesia antara lain sebangai berikut :

1. Informasi tentang Pelaksanaan State Safety Programme (SSP) 
2. Informasi dan regulasi pelaksanaan SMS.

3. Membandingkan antara amanah Undang-Undang nomor 1 tahun 2009 tentang Penerbangan.

Data / Informasi tentang Pelaksanaan State Safety Programme (SSP) dapat diakses melalui http://ssp.hubud.dephub.go.id/id/, yang dikelola oleh Direktorat Jenderal Perhubungan Udara, Kementerian Perhubungan Republik Indonesia, sehingga informasi yang dikeluarkan secara resmi oleh regulator dalam hal ini wakil dari pemerintah RI.

\subsection{Diagram Alur Penelitian}

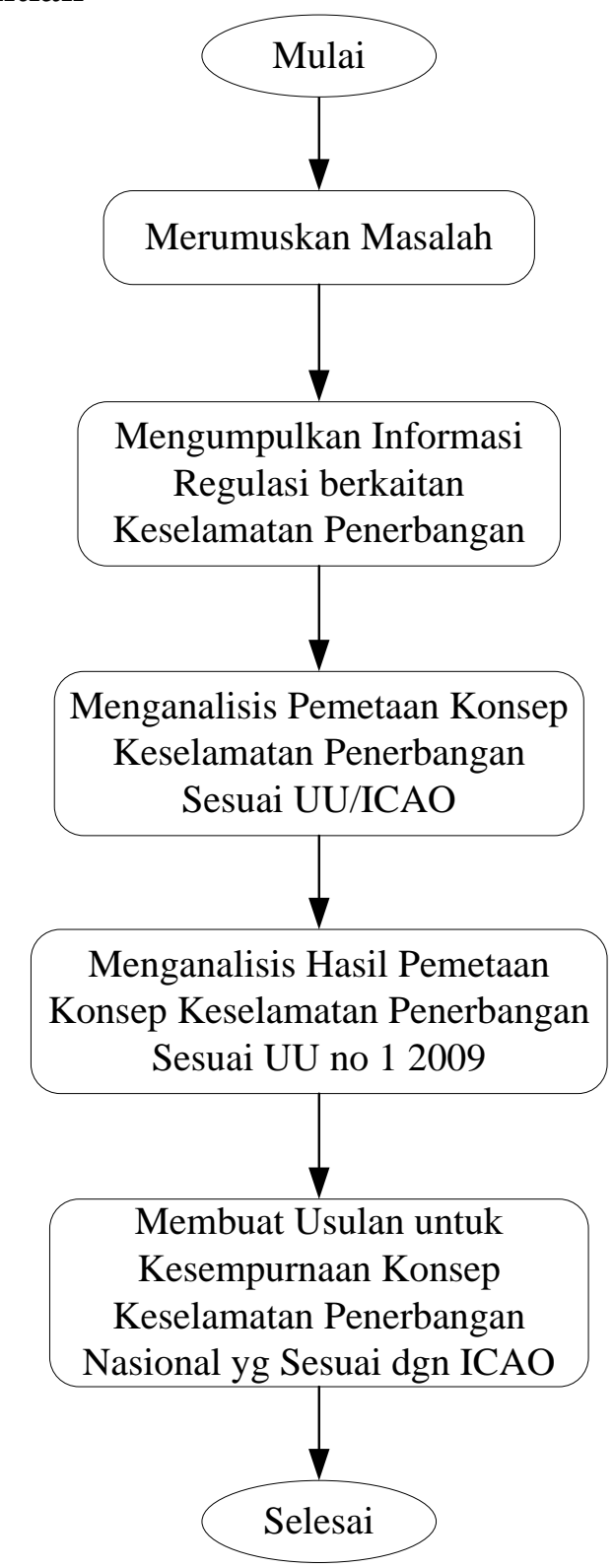

Gambar 2. Diagram Alur Penelitian

\section{Hasil dan Pembahasan}

Undang-Undang Nomor 1 tahun 2009 tentang Penerbangan dalam Pasal 1, Butir 48 menyatakan bahwa "Keselamatan Penerbangan adalah suatu keadaan terpenuhinya persyaratan keselamatan dalam pemanfaatan wilayah udara, pesawat udara, fasilitas umum lainnya". Untuk penyedia jasa penerbangan di Indonesia bahwa tingkat keselamatan 
penerbangan dapat dicapai dengan berfungsinya semua unsure terkait antara satu dengan lainnya terhadap penyedia jasa penerbangan.

Mempertimbangkan kemajuan dan ketangguhan teknologi tinggi dalam penerbangan, analisa kecenderungan (trend analysis) atas kecelakaan penerbangan dan penyedia jasa penerbangan, menyimpulkan sebagian besar dari kecelakaan yang terjadi diakibatkan oleh kesalahan manusia (human error). Dari hasil penelitian yang sudah dilakukan, selain faktor teknis operasional dan cuaca, penyebab utama kecelakaan diakibatkan ketidakdisiplinan atau kurang terpenuhinya kompetensi personel penerbangan dan organisasi. Penggantian personel penerbangan tidak akan mencegah kecelakaan melainkan yang paling penting dilakukan untuk mencegah kecelakaan adalah mengidentifikasi, memahami serta mengendalikan faktorfaktor inti dari penyebab kecelakaan-kecelakaan yang terjadi sebelumnya.

Dalam Undang-Undang No.1 tahun 2009 tentang Penerbangan, bahasan tentang keselamatan penerbangan ini tercantum dalam Bab XIII Keselamatan Penerbangan, yang terdiri dari bahasan tentang Program Keselamatan Penerbangan Nasional (Pasal 308 sampai Pasal 311); Pengawasan Keselamatan Penerbangan (Pasal 312); Penegakan Hukum Keselamatan Penerbangan (Pasal 313); Sistem Manajemen Keselamatan Penyedia Jasa Penerbangan (Pasal 314 sampai Pasal 317); dan Budaya Keselamatan (Pasal 318 sampai Pasal 322). Tanggung jawab terhadap pengawasan keselamatan penerbangan ini dipegang oleh Kementerian Perhubungan, di mana pengawasan keselamatan penerbangan ini merupakan kegiatan pengawasan berkelanjutan untuk melihat pemenuhan peraturan keselamatan penerbangan yang dilaksanakan oleh penyedia jasa penerbangan dan pemangku kepentingan lainnya yang meliputi: audit; inspeksi; pengamatan (surveillance); dan pemantauan (monitoring).

Ada 3 (tiga) metode strategi yang digunakan dalam pengelolaan keselamatan, yaitu: metode reaktif (reactive method), menanggapi kejadian ketika hal tersebut sudah terjadi; metode proaktif (proactive method), melihat secara aktif untuk mengidentifikasi setiap risiko keselamatan melalui analisis aktivitas-aktivitas yang dilakukan organisasi; dan metode prediktif (predictive method), memetakan kinerja sistem dalam kondisi operasional normal saat ini untuk mengidentifikasi permasalahan potensial yang dapat terjadi di masa datang (ICAO Doc.9859 Safety Management Manual).

Pengelolaan keselamatan (safety management) mempunyai dua dimensi, yaitu safety management process, merujuk pada berbagai proses yang memuat berbagai kegiatan di mana tingkat keselamatannya (level of safety) harus dikontrol, dan safety management organization, melibatkan tanggung jawab (responsibilities), kompetensi, komitmen, dan komunikasi yang baik antar organisasi atau perseorangan yang terlibat dalam proses pengelolaan keselamatan tersebut (National Aerospace Laboratory, 2003).

Elemen-elemen kunci dari safety management process adalah: safety policy, pernyataan tentang pengaturan tujuan keselamatan dari manajemen tertinggi yang bertanggung jawab; decision making, berdasarkan safety policy yang diadaptasi menjadi keputusan organisasi; safety monitoring, proses penilaian tentang level of safety yang sekarang ada di sistem penerbangan; threat identification, proses untuk mengidentifikasi kondisi-kondisi yang mungkin memiliki pengaruh yang serius terhadap tingkat keselamatan yang ada; risk assessment, proses untuk menilai risiko yang berhubungan dengan potential safety threats; dan safety actions, kegiatan yang harus dilakukan dalam upaya untuk memperbaiki defisiensi keselamatan ataupun mitigasi risiko. Proses ini sesuai dengan siklus kegiatan sistematis untuk mencapai tujuan keselamatan, yaitu rencanakan $\rightarrow$ lakukan $\rightarrow$ periksa $\rightarrow$ tindakan. 


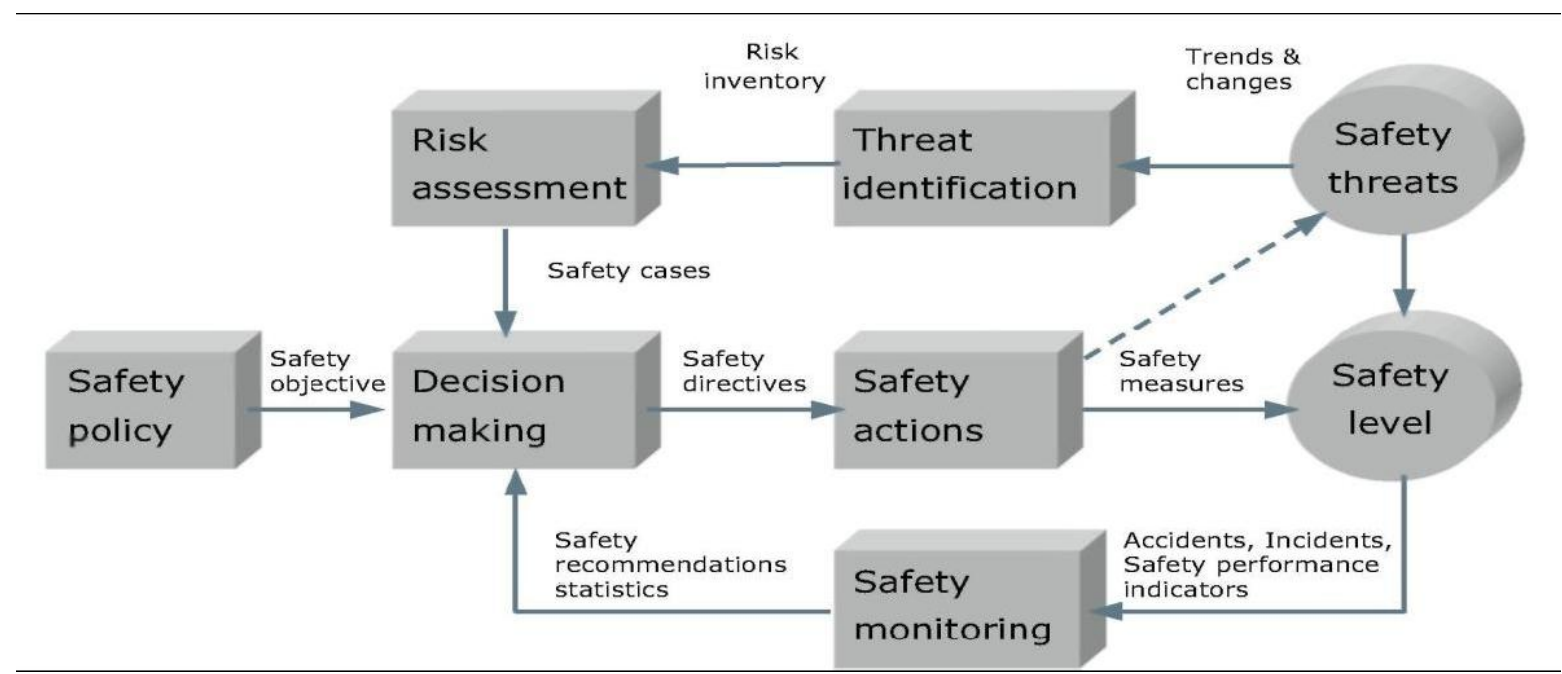

Gambar 3.The general safety management process

Berdasarkan gambar Struktur Pengelolaan Database Keselamatan Penerbangan Nasional, Setiap stakeholder penerbangan harus menjalankan SMS dan membuat laporan pelaksanaannya tiap periodik ke regulator untuk menjadi masukkan dalam menyusun laporan kinerja keselamatan penerbangan nasional.Keselamatan penerbangan merupakan tanggung jawab seluruh pemangku kegiatan di bidang penerbangan, dorongan untuk mematuhi dan mengikuti standar tingkat keselamatan harus dimulai dari tingkat tertinggi manajemen di setiap organisasi.

Keselamatan penerbangan adalah kunci bagi penyedia jasa penerbangan agara dapat berkontribusi dalam memenuhi kepentingan negara. Standar ICAO menyatakan prioritas utama dalam penerbangan adalah tercapainya sebuah sitstem yang selamat (safe). Tindakan untuk mewujudkan keselamatan penerbangan harus didukung oleh fakta, data dan persepsi masyarakat mengenai unsur- unsur yang dibutuhkan untuk mencapai keselamatan.

Tingkat risiko keselamatan yang dapat diterima berpengaruh terhadap sistem keselematan penerbangan, yang akan menurun jika terjadi kecelakaan. Kejadian serius dan kecelakaan dapat merusak nama baik penyedia jasa penerbangan, Pemerintah dan negara. Dalam kejadian serius dan kecelakaan, faktor kesalahan manusia berkontribusi terbesar. Kelemahan fungsi-fungsi manajemen sangat terkait dengan banyaknya kesalahan tersebut.

\section{Pelaksanaan Safety Management System di Penyedia Jasa Penerbangan}

Peraturan Menteri Perhubungan Republik Indonesia nomor PM 62 tahun 2017 tentang Peraturan Keselamatan Penerbangan Sipil (PKPS) Bagian 19 tentang Sistem Manajemen Keselamatan (Safety Management System) yang telah dikeluarkan mewajibkan seluruh stakeholder Penerbangan (Mandatory dan Voluntory Reporting) untuk berpartisipai meningkatkan keselamatan penerbangan. Gambaran pelaksanaan Safety Management System dapat dipetakan dari aspek regulasi adalah sebagai berikut : 
Peraturan Menteri Perhubungan Republik Indonesia nomor PM 62 tahun 2017 tentang Peraturan Keselamatan Penerbangan Sipil (PKPS) Bagian 19 tentang Sistem Manajemen Keselamatan (Safety Management System)
Peraturan Direktur Jenderal Perhubungan Udara nomor : KP 622 tahun 2015, tentang Petunjuk Teknis Peraturan Keselamatan Penerbangan Sipil (PKPS) Bagian 139-08, Penerimaan (Acceptance) Pelaksanaan Sistem Manajemen Keselamatan (Safety Management System) Bandar Udara

Yang dimaksud dengan Penyedia Jasa Penerbangan, menurut UU no. 1 thn 2009, tentang Penerbangan :

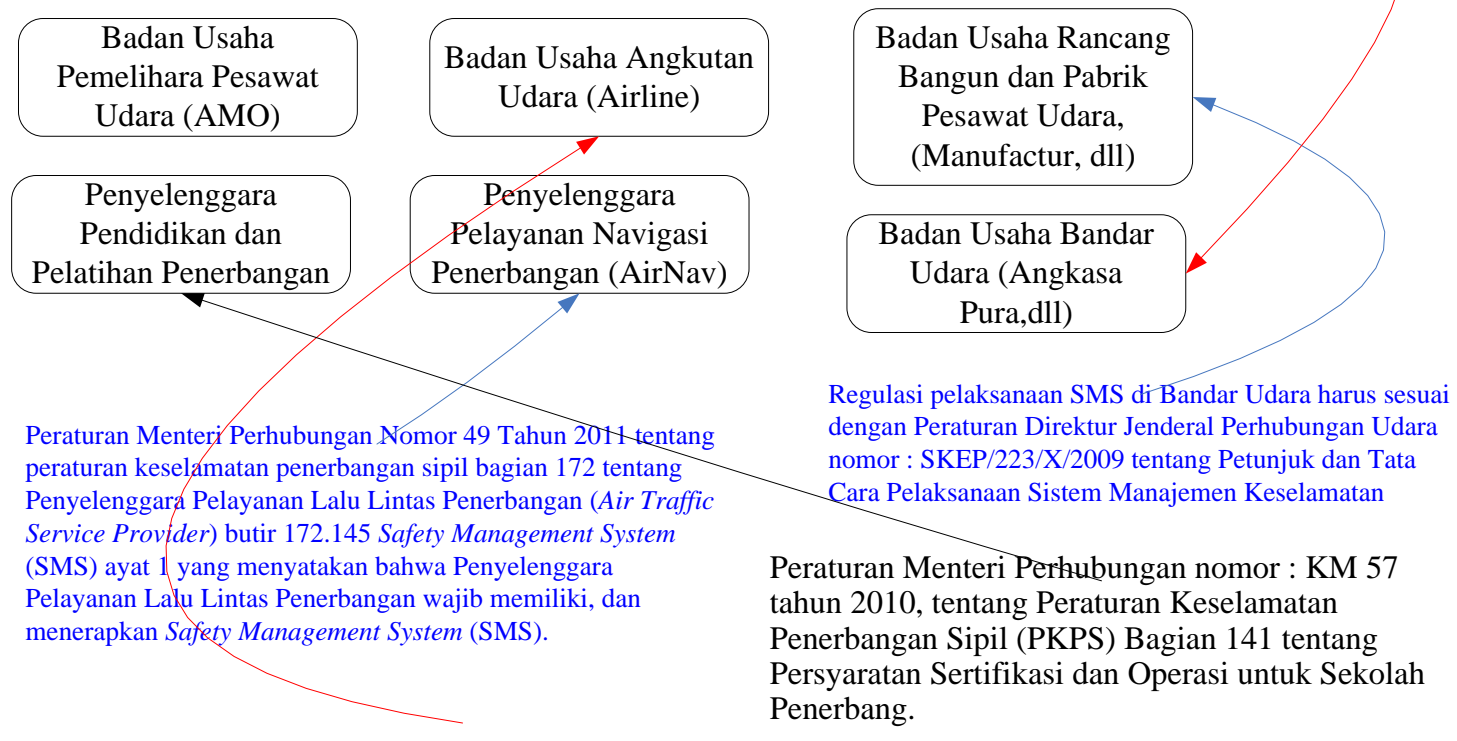

UU no 1 tahun 2009, Bagian Kedua : Operasi Pesawat Udara, Pasal 42 :

Untuk mendapatkan sertifikat operator pesawat udara sebagaimana dimaksud dalam Pasal 41 ayat (2) huruf a operator harus: m. memiliki pedoman sistem manajemen keselamatan (safety management system manual).

Gambar 4 Pemetaan Pelaksanaan Safety Management System Penyedia Jasa Penerbangan

Gambar 4.3 menunjukkan bahwa program keselamatan yang wajib dilaksanakan oleh seluruh penyedia jasa penerbangan sudah terlaksana atau dijalankan oleh seluruh stakeholder, secara persyaratan minimal sesuai dengan PM 62 tahun 2017 tentang Peraturan Keselamatan Penerbangan Sipil (PKPS) Bagian 19 tentang Sistem Manajemen Keselamatan (Safety Management System). Selanjutnya seluruh stakeholder menyusun laporan pelaksanaan Safety Management System (SMS) disampaikan kepada Direktorat Jenderal Perhubungan Udara sebagai bahan rujukan pengembangan keselamatan penerbangan berkelanjutan bagi pelaksanaan Program Keselamatan Penerbangan Nasional. Selain pelaporan yang bersifat wajib (mandatory) seperti pelaksanaan wajib SMS ada juga yang bersifat sukarela (voluntary). Laporan Sukarela adalah penyampaian informasi yang dilakukan secara sukarela oleh masyarakat kepada Direktorat Jenderal Perhubungan Udara tanpa diharuskan oleh peraturan yang berlaku atau pengungkapan informasi melebihi yang diwajibkan terhadap setiap kejadian yang secara nyata teridentifikasi dapat mengancam keselamatan penerbangan.

UU nomor 1 tahun 2009 tentang Penerbngan, Bagian Keempat : Sistem Manajemen Keselamatan Penyedia Jasa Penerbangan, Pasal 315 : Sistem manajemen keselamatan penyedia jasa penerbangan sebagaimana dimaksud dalam Pasal 314 ayat (1) paling sedikit memuat:

a. kebijakan dan sasaran keselamatan;

b. manajemen risiko keselamatan; 
c. jaminan keselamatan; dan

d. promosi keselamatan.

Berdasarkan regulasi ini, maka pelaksanaan Safety Management System seharusnya tuntas sampai statement promosi keselamatan dilakukan. Promosi dapat dijalankan jika kegiatan pengukuran kinerja keselamatan dilakukan secara periodik dijalankan oleh regulator dalam hal ini perhubungan udara, sehingga tiap periodik perhubungan udara menyampaikan hasil kinerja seluruh stakeholder terhadap program keselamatan penerbangan yang sudah dijalankan kemudian dipublikasikan kepada masyarakat. Hal ini sesuai dengan ketentuan dalam UU no. 1 tahun 2009, Pasal 316, ayat (2) Penetapan target kinerja keselamatan sebagaimana dimaksud pada ayat (1) huruf d yang akan dicapai harus minimal sama atau lebih baik daripada target kinerja keselamatan nasional. Dan ayat (3) Target dan hasil pencapaian kinerja keselamatan harus dipublikasikan kepada masyarakat.

Berdasarkan uraian di atas, maka dipastikan pelaksanaan SMS yang wajib dilaksanakan selama ini oleh seluruh stakeholder penerbangan belum dijalankan sepenuhnya sesuai dengan State Safety Programme (SPP) yang sudah diamanatkan oleh ICAO, karena harusnya secara periodik Perhubungan Udara membuat laporan kinerja keselamatan penerbangan di Indonesia yang disampaikan ke Publik/Masyarakat. Hal inilah yang perlu diperbaiki sehingga point terakhir "Promosi Keselamatan" sebagai hal minimal terakhir dari SMS dapat dijalankan secara sempurna.

\section{Penegakan hukum.}

Penegakan hukum merupakan cara untuk mengambil tindakan kepada personel penerbangan berlisensi dan penyedia jasa penerbangan bersertifikat yang tidak memenuhi persyaratan minimum yang ditentukan dalam Peraturan Keselamatan Penerbangan Sipil (PKPS). Menteri berwenang menetapkan program penegakan hukum dan mengambil tindakan hukum di bidang keselamatan penerbangan. Penegakan hukum dilakukan dalam bentuk sanksi administratif dan sanksi pidana. Sanksi administratif diberlakukan terhadap pelanggaran peraturan perundang-undangan bidang keselamatan penerbangan dalam bentuk peringatan, pembekuan, pencabutan, dan sanksi denda administratif.

Sanksi administratif terhadap pelanggaran peraturan perundang- undangan bidang keselamatan penerbangan ditetapkan oleh Direktur Jenderal berdasarkan hasil pemeriksaan Inspektur Penerbangan. Terhadap pelanggaran peraturan perundangundangan bidang keselamatan penerbangan yang terbukti terdapat unsur pidana maka akan dilakukan penyidikan oleh Penyidik Pegawai Negeri Sipil (PPNS).

Berdasarkan UU nomor 1 tahun 2009 tentang Penerbangan, Bagian Ketiga : Penyelidikan Lanjutan Kecelakaan Pesawat Udara, pasal 364 menyatakan "Untuk melaksanakan penyelidikan lanjutan, penegakan etika profesi, pelaksanaan mediasi dan penafsiran penerapan regulasi, komite nasional membentuk majelis profesi penerbangan". Dilanjutkan pasal 365, menyatakan : Majelis profesi penerbangan sebagaimana dimaksud dalam Pasal 364 mempunyai tugas: (a) menegakkan etika profesi dan kompetensi personel di bidang penerbangan; (b) melaksanakan mediasi antara penyedia jasa penerbangan, personel dan pengguna jasa penerbangan; dan (c) menafsirkan penerapan regulasi di bidang penerbangan. Berkaitan dengan wewenangnya sesuai dengan pasal 368, UU nomor 1 tahun 2009, Majelis profesi penerbangan berwenang: (a) memberi rekomendasi kepada Menteri untuk pengenaan sanksi administratif atau penyidikan lanjut oleh PPNS; (b) menetapkan keputusan 
dalam sengketa para pihak dampak dari kecelakaan atau kejadian serius terhadap pesawat udara; dan (c) memberikan rekomendasi terhadap penerapan regulasi penerbangan.

Untuk menyelesaikan permasalahan personil yang melanggar tugas dan wewenangnya dalam menjalankan profesi di industri penerbangan sehingga yang bersangkutan diberikan sanksi, seharusnya pemerintah dalam hal ini melalui perhubungan udara harus membentuk "Majelis Profesi Penerbangan", sehingga pelanggaran yang telah dilakukan akan mendapatkan sanksi sesuai dan obyektif menurut UU yang berlaku. Pelaksanaan Safety Management System (SMS) harus dijalankan secara utuh oleh seluruh stakeholder dalam hal ini Pemerintah (Perhubungan Udara) sebagai regulator-pun harus patuh melaksanakan sesuai dengan Undang-Undang yang berlaku.

\section{Kesimpulan}

Berdasarkan pembahasan yang telah diuraikan sebelumnya, maka dapat dibuat beberapa kesimpulan sebagai berikut :

1. Setiap stakeholder industri penerbangan telah menjalankan kewajiban melaksanakan SMS secara syarat minimal, tetapi belum sempurna karena kegiatan promosi keselamatan harus dilakukan menunggu penilaian akhir dari pemerintah dalam hal ini perhubungan udara yang harus menganalisis dan menilai laporan pelaksanaan SMS stakeholder dan mempublikasikan kepada masyarakat secara periodik, belum terlaksana sepenuhnya sesuai dengan target menurut regulasi yang berlaku.

2. Untuk menyelesaikan permasalahan personil yang melanggar tugas dan wewenangnya dalam menjalankan profesi di industri penerbangan sehingga yang bersangkutan diberikan sanksi, seharusnya pemerintah dalam hal ini melalui perhubungan udara harus membentuk "Majelis Profesi Penerbangan", sehingga pelanggaran yang telah dilakukan akan mendapatkan sanksi sesuai dan obyektif menurut UU yang berlaku.

3. Pelaksanaan SMS sebagai bagian dari State Safety Programme (SSP) sesuai dengan amanah ICAO belum dapat dijalankan sepenuhnya oleh Pemerintah sebagai regulator yang menjalankan Program Keselamatan Penerbangan Nasional.

Berdasarkan kesimpulan yang disampaikan di atas, maka untuk menyempurnakan pelaksanaan SMS oleh stakeholder industri penerbangan, ada beberapa saran yang diberikan kepada pemerintah untuk segera membenahi regulasi penerbangan, dalam hal :

1. Perhubungan udara harus secara periodik melakukan analisis dan penilaian pelaksanaan SMS yang telah diberikan stakeholder, sehingga "Promosi Keselamatan" Penerbangan dapat dijalankan sebagai bagian dari Program Keselamatan Penerbangan Nasional.

2. Pemerintah segera membentuk "Majelis Profesi Penerbangan", sehingga personilpersonil yang melakukan pelanggaran akan mendapatkan sanksi yang obyektif.

\section{Daftar Pustaka}

[1] Kementerian Perhubungan (2012), “UU No.1 Tahun 2009 Tentang Penerbangan".

[2] ICAO (2009), Safety Management Manual (SMM), Doc 9859, AN 474, Second edition, International Civil Aviation Organization, Montreal.

[3] Poerwanto, E., Sajati, H., \& Andaruwati, R. (2018, November). The Ergonomic Analysis of the Airline Passengers Message Service to Improve the Flight Safety. In Conference SENATIK STT Adisutjipto Yogyakarta (Vol. 4, pp. 201-210).

[4] Poerwanto, E., \& Mauidzoh, U. (2016). Analisis Kecelakaan Penerbangan Di Indonesia Untuk Peningkatan Keselamatan Penerbangan. Angkasa: Jurnal Ilmiah Bidang Teknologi, 8(2), 9-26. 
[5] Peraturan Menteri Perhubungan Republik Indonesia. (2017) Nomor PM 62 tahun 2017 tentang Peraturan Keselamatan Penerbangan Sipil (PKPS) Bagian 19 tentang Sistem Manajemen Keselamatan (Safety Management System).

[6] Peraturan Menteri Perhubungan Republik Indonesia (2016) Nomor : PM 93 tahun 2016, tentang Program Keselamatan Penerbangan Nasional.

[7] ICAO (2010), “Annex 13 Aircraft Accident and Incident Investigation”, Tenth Edition, International Civil Aviation Organization, Montreal

[8] Undang-Undang Nomor 1 tahun 2009 tentang Penerbangan.

[9] Wastuadhi, A. P. (2012). Penyelenggaraan Penyelidikan Dalam Mencari Penyebab Kecelakaan Pesawat Udara Sipil Yang Terjadi Di Wilayah Indonesia (Doctoral dissertation, Tesis Fakultas Hukum, Program Pascasarjana, Kekhususan Sistem Peradilan Pidana, Universitas Indonesia, Jakarta). 